\title{
Küçük Menderes Havzasında İklim Değişikliğinin Olası Etkileri ve Üreticilerin Konuya İlişkin Farkındalıkları
}

\author{
Yarkın AKYÜZ (D) Ela ATIŞ \\ Ege Üniversitesi Ziraat Fakültesi Tarım Ekonomisi Bölümü, Bornova/İzmir \\ $\bowtie$ : yarkinakyuz@gmail.com
}

\section{ÖZET}

İklim değişikliği tüm insanlığı ve insanlığın gerçekleştirdiği tüm ekonomik faaliyetleri doğrudan ya da dolaylı olarak etkilemektedir. $\mathrm{Bu}$ ekonomik faaliyetler arasında iklim değişikliğinden en çok etkilenecek sektör tarım sektörüdür. Tarımda risk ve belirsizlik söz konusudur. Tarımsal üretim fonksiyonu içerisinde iklim bağımsız bir değişken olarak yer almakta ve sinırlı bir tahmin durumu bulunmaktadır. Tarımsal faaliyetin beklenen şekilde gerçekleşmesi için iklim koşullarının uygun olması gerekmektedir. Bu sebeple iklimde meydana gelecek olan küçük değişiklikler bile, iklimle doğrudan bağlantısı bulunan tarımsal faaliyeti etkileyecektir. Çalışma, geleceğe dönük projeksiyonlarda $3-5{ }^{\circ} \mathrm{C}$ 'lik sıcaklık artışları ve \%10-20 aralığında yağış azalması beklenen ve bu açıdan risk altında bulunan Küçük Menderes Havzası bazında iklim değişikliğinin etkilerini incelemek ve üreticinin bu konudaki farkındalıklarını ortaya koymak amaçlanmıştır. $\mathrm{Bu}$ amaçla çalışmada, Küçük Menderes Havzası'nda iklim değişikliğinden kaynaklanan sıcaklık ve yağıştaki değişimler için daha önce yapılmış senaryolara dayalı çalışma sonuçlarından yararlanılmıştır. Bunun yanında, iklim değişikliği karşısında havza üreticilerinin farkındalıkları ve olası etkilere yönelik çözümler üreticilerle (171 üretici) yapılan yüz yüze anketler yolu ile elde edilen veriler yardımıla ortaya konmuştur.

\section{Possible Impacts of Climate Change in the Küçük Menderes Basin and Farmers' Awareness}

\section{ABSTRACT}

Climate change affects whole humanity and economic activities of human directly or indirectly. Among the sectors that most severely affected by climate change is the agriculture. There is risk and uncertainty in agriculture. Climate agrees as an independent variable in the agricultural product function and has a limited forecast situation. The climatic conditions required to be suitable for the expected agricultural activity. Therefore, even small changes in the climate will affect the agricultural activity which is directly connected to the climate. The aim of the study was to examine the effects of climate change on the basis of Küçük Menderes Basin, which is expected to decrease $3-5{ }^{\circ} \mathrm{C}$ in the projections and decrease in rainfall in the range of $10-20 \%$ and and to reveal farmers' awereness on impacts of climate change. For this purpose, the results of the studies based on previous scenarios were used for the changes in temperature and rainfall caused by climate change for the Küçük Menderes Basin. In addition, the awareness of basin farmers' and possible solutions was presented by means of face-to-face surveys conducted with farmers (171 farmers).
Makale Tarihçesi

Geliş : 20.10.2018

Kabul : 27.12.2018

Anahtar Kelimeler
Iklim Değişikliği,
Tarım,
Üretici Farkındalığı,
Küçük Menderes Havzası.

Araştırma Makalesi

Article History

Received : 20.10.2018

Accepted : 27.12.2018

Keywords
Climate Change,
Agriculture,
Farmer Awareness,
Küçük Menderes Basin.

\section{Research Article}

To cite: Yarkın A, Atış E 2018. Küçük Menderes Havzasında İklim Değişikliğinin Olası Etkileri ve Üreticilerin Konuya ilişkin Farkındalıkları. KSÜ Tar Doğa Derg 21(Özel Sayı) : 109-115, DOI : 10.18016/ ksutarimdoga.vi.472836 


\section{GİRIŞ}

İklim değişikliğinin olumsuz etkileri tüm dünyada şimdiden hissedilmekte ve özellikle Türkiye gibi yarıkurak iklim kuşağında yer alan bir ülke için durum tehlike arz etmektedir. İklim değişikliğinin pek çok tanımı olmakla beraber, genel bir yaklaşımla; nedeni ne olursa olsun iklim koşullarındaki küresel ve önemli yerel etkileri bulunan, uzun süreli ve yavaş gelişen değişiklikler biçiminde tanımlanmaktadır (Türkeş, 1997). BM İklim Değişikliği Çerçeve Sözleşmesine göre ise; "karşılaştırılabilir zaman dilimlerinde gözlenen doğal iklim değişikliğine ek olarak, doğrudan veya dolaylı olarak küresel atmosferin bileşimini bozan insan faaliyetleri sonucunda iklimde oluşan bir değişiklik" şeklinde tanımlanmıştır (UNFCCC, 1992). Tanımların da üzerinde durduğu gibi iklim değişikliği; doğal olan bir süreç olmasına rağmen, insan eli ile etkilerini arttırmış ve mevcut süreç hızlanmıştır. Benzer şekilde, Schreiner ve arkadaşları (2005) sera gazlarının etkisiyle iklim sisteminin değişmesine yol açan küresel ısınmayı insanoğlunun etkisiyle (bilimsel, politik, ekonomik ve etik alanlarda) ortaya çıkan ve 21. yüzyılda üzerinde tartışılması gereken en büyük çevre sorunu olarak tanımlamışlardır.

İklim değişikliği tüm insanlığı ve dolayısı ile insanlığın gerçekleştirdiği tüm faaliyetleri doğrudan ya da dolaylı olarak etkilemektedir. İklim değişikliği göz önünde bulundurulduğunda belki de en çok etkilenecek sektör tarım sektörüdür. Tarım, doğada yapılan bir faaliyet olmasından dolayı pek çok sorunla boğuşmaktadır. Bunların bir kısmına müdahale edilebilirken, müdahale edilemeyen en önemli etmen iklimdir (Akyüz ve Atış, 2016). Bu durumun temel sebebi iklimde yaşanması muhtemel değişikliklerin çok önceden belirlenememesi ve alınabilecek önlemlerin sinırlı olmasıdır. Tarımsal faaliyet sirasında müdahalede bulunulabilecek ve etkisi azaltılabilecek pek çok faktör bulunmakla beraber iklim bunlardan biri değildir. Çünkü tarımsal faaliyetin beklenen şekilde gerçekleşebilmesinin temelinde iklim yatmaktadır. Tarım yapıldığı bölgenin ikliminden doğrudan etkilenmekte ve yetiştirilecek ürünün çeşidinden miktarına kadar birçok faktör üzerinde söz sahibi olarak iklim karşımıza çıkmaktadır. Bu durumda tarımın yapıldığı bölgenin iklime bağlı olarak şekillendiğinden bahsedebiliriz. $\mathrm{Bu}$ sebeple iklimde meydana gelecek olan küçük değişiklikler dahi iklimle doğrudan bağlantısı bulunan tarımsal faaliyetleri etkileyecektir. Kısacası, tarımsal üretim fonksiyonu içerisinde iklim bağımsız bir değişken olarak yer almakta ve sinırlı bir tahmin durumu bulunmaktadır.

Tarımın iklim değişikliğinden ne şekilde etkilendiğini ortaya koymak üzere yapılmış ulusal (Dellal ve ark, 2011; Dellal ve ark,2016) ve uluslararası (Cline, 2007; IFPRI, 2009) çalışmalar bulunmaktadır. Bu çalışmalar incelendiğinde iklim değişikliği nedeni ile gelecekte tarımda verimlerde düşüşler yaşanacağı ve tarımsal ürün fiyatlarında artışlar ortaya çıkacağı sonucuna varılmaktadır.

Türkiye'de yapılan çalışmalara göre kıyı bölgelerde ortalama sicaklıklarda 5-6 ${ }^{\circ} \mathrm{C}$, özellikle Ege Bölgesinde yaz ayları süresince $7-8{ }^{\circ} \mathrm{C}$ artış, yağışlarda $\% 40$ 'lık bir azalma beklenmektedir (Demir ve ark., 2014; MGM, 2014). Bu değişikliklerden havzada yapılan tarımsal üretimin etkilenmemesi mümkün değildir. Ege bölgesinin önemli akarsu havzalarından olması, iklim değişikliğinden halihazırda ve gelecekte etkilenmesi ve uzun yıllardır tarımsal faaliyetin gerçekleştirildiği bir havza olması açısından Küçük Menderes havzasının durumunun ortaya konulup çeşitli önlemler alınması elzemdir.

Özellikle Meteoroloji Genel Müdürlüğü tarafından yapılan bir çalışmada (2014) yer alan havza bazlı projeksiyonlara göre, havzada gelecekte sicaklık değerlerinde ortalama $3-5{ }^{\circ} \mathrm{C}$ 'lik artışlar yaşanacağı görülmektedir. $\mathrm{Bu}$ artışın sürekli olarak gerçekleşeceği de denkleme dahil edildiğinde havzanın mevcut durumda yaşadığı kuraklık gelecekte daha da büyük bir problem teşkil edecektir. Yine aynı çalışmada, yağışların ise özellikle projeksiyonun ilk döneminde (2011-2040) artma eğiliminde olmakla beraber ikinci ve üçüncü dönemde \%10-20 aralığında bir azalış göstereceği sonucunda ulaşılmıştır. Bu durumda zaten kuraklık yaşayan ve tarımsal kuraklık riski giderek artan havzanın bir de yağışların azalması ile su arzı açısından daha da zor günler geçireceğini söylemek şaşırtıcı olmayacaktır.

$\mathrm{Bu}$ veriler ışığında çalışmada, havzanın iklimsel olarak mevcut ve gelecekteki durumu ortaya konulmuş, Küçük Menderes Havzası üreticilerinin iklim değişikliği algısı belirlenmiş ve elde edilen veriler doğrultusunda havzanın durumu da göz önüne alınarak havza için çeşitli önerilerde bulunulmuştur.

\section{MATERYAL ve YÖNTEM}

Çalışmanın ana materyalini, Küçük Menderes Havzasında yer alan; Ödemiş, Bayındır, Tire ve Beydağ ilçelerindeki üreticilerle, 2017 yılının son çeyreğinde yüz yüze anketler yoluyla elde edilmiş birincil veriler oluşturmaktadır. Çalışmanın ikincil verileri olarak, Meteoroloji Genel Müdürlüğü verileri, havza ve iklim raporları (T.C. Çevre ve Şehircilik Bakanlığı, 2013 ve 2016) incelenmiştir. Ayrıca konu üzerine yapılmış ulusal ve uluslararası makale, tez ve araştırmalar ele alınmıştır.

İzmir İl Tarım ve Orman Müdürlüğü verilerine göre, araştırma alanı olarak belirlenen ilçelerin çiftçi sayısı anakitle olarak kabul edilmiş ve örnek hacmi buna göre hesaplanmıştır. Örnek hacmi, oransal örnek hacmi formülüne göre, $\% 95$ güven aralığı $\% 7,5$ hata payı ile 171 üretici olarak belirlenmiştir (Newbold, 1995). Bu değer, araştırma alanında seçilen ilçelerdeki toplam çiftçi sayısına oranlanarak her ilçede kaç çiftçi 
ile görüşüleceği tespit edilmiş ve bu ilçelerden seçilmiş köylerde gerçekleştirilen anket çalışmasında çiftçilerle yüz yüze görüşme yoluyla anket formları doldurulmuştur. Havzanın durumu ele alınırken rapor verileri yorumlanmıştır. Araziden elde edilen orijinal veriler için ise çeşitli ölçeklerden yararlanılarak yeni ölçekler geliştirilmiştir. Bu verilerin analizi sırasında tanımlayıcı istatistiklerden ve 5'li likert ölçeğinden yararlanılmıştır.

\section{KÜÇÜK MENDERES HAVZASI HAKKINDAKI GENEL BİLGİLER}

\section{Havzanin Konumu ve Su Kaynakları}

Türkiye geneli hidrolojik çalışmalar için 25 ana akarsu havzasına ayrılmıştır. Bu havzalardan olan Küçük Menderes Havzası, Türkiye'nin batısında Gediz ve Büyük Menderes Havza'ları arasında, sularını Küçük Menderes Nehri ve diğer akarsularla Ege Denizi'ne boşaltan alanı kapsamaktadır. Havza bünyesinde üç ilden ilçeleri barındırmaktadır. İller havza sınırları içerisinde kalan alanlarının büyüklükleri göre; İzmir (\%95), Aydin (\%4), Manisa (\%1) olarak sıralanmaktadır (T.C. Orman ve Su İşleri Bakanlığı, 2016).

Havzadaki arazilerin \%39'u tarımsal alan, \% 55’i orman ve yarı doğal alan, \%5’i yapay alan ve \%1'i su yüzeylerinden oluşmaktadır (T.C. Orman ve Su İşleri Bakanlığı, 2016). T.C. Çevre ve Orman Bakanlığ tarafindan bir proje kapsamında hazırlanan Havza Koruma Eylem Planları'na (2010) göre, havzayı temsil eden akarsu, Küçük Menderes Nehri ve kollarıdır.

Ayrıca, Muluk ve arkadaşlarının 2013 yılında gerçekleştirdiği çalışmada, Falkenmark su stres endeksine göre havzalarda kişi başına düşen su miktarları ortaya konmuş ve Küçük Menderes Havzası dikkat çekici olarak havzalar arasında koyu kırmızı rengi ile mutlak su kıtlı̆̆ içerisinde olan tek havza olarak görülmektedir. $\mathrm{Bu}$ durumda da içme suyu yetersizliğinde ve olası bir kuraklık durumunda bir diğer tatlı su kaynağı olan tarımsal sulama suyu kaynakları içme suyu ihtiyacına yönlendirilecek ve tarımsal sulama suyu ihtiyacı daha da artacak, havzadaki tarımsal faaliyetler bu durumdan olumsuz etkilenecektir.

\section{Havzanın İklimsel Yapısı}

Küçük Menderes Havzası'nda, Akdeniz iklim özellikleri etkilidir. Akdeniz ikliminde; yazlar sıcak ve kurak, kışlar ise ılık ve yağışlıdır. Yıllık toplam yağışın yaklaşık yarısı kışın düşmektedir. Kıyı kuşağında, kar yağışı ve don olayları nadir olarak görülür. Yüksek kesimlerde kışlar, karlı ve soğuk geçmektedir. Kuraklık fazla değildir. Yarı nemli kuşakta yer alan Küçük Menderes Havzası sınırının doğusu ve güneydoğusunun toplam yağış miktarı, bölgenin diğer kısmından daha fazladır. Havzanın en az yağış aldığı ay Ağustos ayı, en çok yağış aldığı ay ise Aralık ayıdır (T.C. Orman ve Su İşleri Bakanlığı, 2016).

Havza yağış açısından incelendiğinde, yıllar itibari ile dalgalanmalar görülmekte ve bazı yıllarda kuraklıklar yaşandığı dikkat çekmektedir. Ancak, genel eğilim incelendiğinde yıllar içerisinde yağışlarda azda olsa bir artış söz konusudur (MGM, 2016).

Küçük Menderes Havzası'nda yer alan istasyonlardan alınan sıcaklık verilerine göre yıllık ortalama sıcaklık değerleri $16,3^{\circ} \mathrm{C}$ 'dir. Ortalama sıcaklıklar bakımından hiçbir ayın ortalamasının $0^{\circ} \mathrm{C}$ altına düşmediği görülmektedir. Soğuk devreyi karakterize eden sürede ortalama sicaklıklar $8^{\circ} \mathrm{C}$ üzerindedir. Sicak devreyi karakterize eden yaz aylarında ise ortalama sıcaklık $25^{\circ} \mathrm{C}$ üzerindedir. Sicak aylar ise Temmuz ve Ağustos'tur (T.C. Orman ve Su İşleri Bakanlığı, 2016). Havza sıcaklık açısından ele aldığında, yıllar itibari ile sürekli bir artıştan söz etmek mümkündür. Havza yıllık ortalama sicaklık değerleri açısından değerlendirildiğinde; 1970-2016 yılları arasında yaklaşık $2^{\circ} \mathrm{C}$ 'lik bir artıştan bahsetmek mümkündür (MGM, 2016).

\section{İklim Değişikliğinin Küçük Menderes Havzasında Olası Etkileri}

Meteoroloji Genel Müdürlüğünün 2014 yılında yaptığı çalışmada; bölgesel iklim modeli (RegCM4.3.4) kullanılmış ve temelinde IPCC 5. Değerlendirme Raporu için hazırlanan HadGEM2-ES Küresel Dolaşım Modeli ailesi içinde üretilen RCP4.5 ve RCP8.5 senaryolarının çıkışlarından ölçek küçültme yöntemi ile daha yüksek bir çözünürlüğe sahip iklim projeksiyonları üretilmiş ve akarsu havzaları bazında iklim değişikliğinin etkileri incelenmiştir.

RCP 4.5 senaryosuna göre sıcaklıklar incelendiğinde bütün havzalarımızda ortalama sıcaklıkların, bütün dönemlerde artış eğiliminde olduğu görülmektedir. En fazla artış ise 3.5-4.0 oC artışla, 2071-2099 döneminde Frrat-Dicle ve Van Gölü havzalarında göze çarpmaktadır. Yağışlar incelendiğinde, Türkiye geneli yağış ortalamasında tüm 2013-2099 döneminde azalmalar görülürken, Marmara, Küçük Menderes, Van Gölü, Kuzey Ege, Aras ve Meriç-Ergene havzalarında tüm dönemlerde artışlar görülmektedir. Bazı havzalarda ise ilk dönemde artış diğer dönemlerde azalmalar dikkat çekmektedir (Şekil 1)

RCP 8.5 senaryosuna göre sıcaklıklar incelendiğinde bütün havzalarda ortalama sıcaklıkların, bütün dönemlerde artış eğiliminde olduğu görülmektedir. 
Yağışlar incelendiğinde, Türkiye geneli yağış ortalamasında ilk dönemde artış, 2 . ve 3 . dönemlerde azalmalar görülürken, Küçük Menderes Havzası için de durum Türkiye geneli ile paralel bir seyir izlemektedir (Şekil 2).

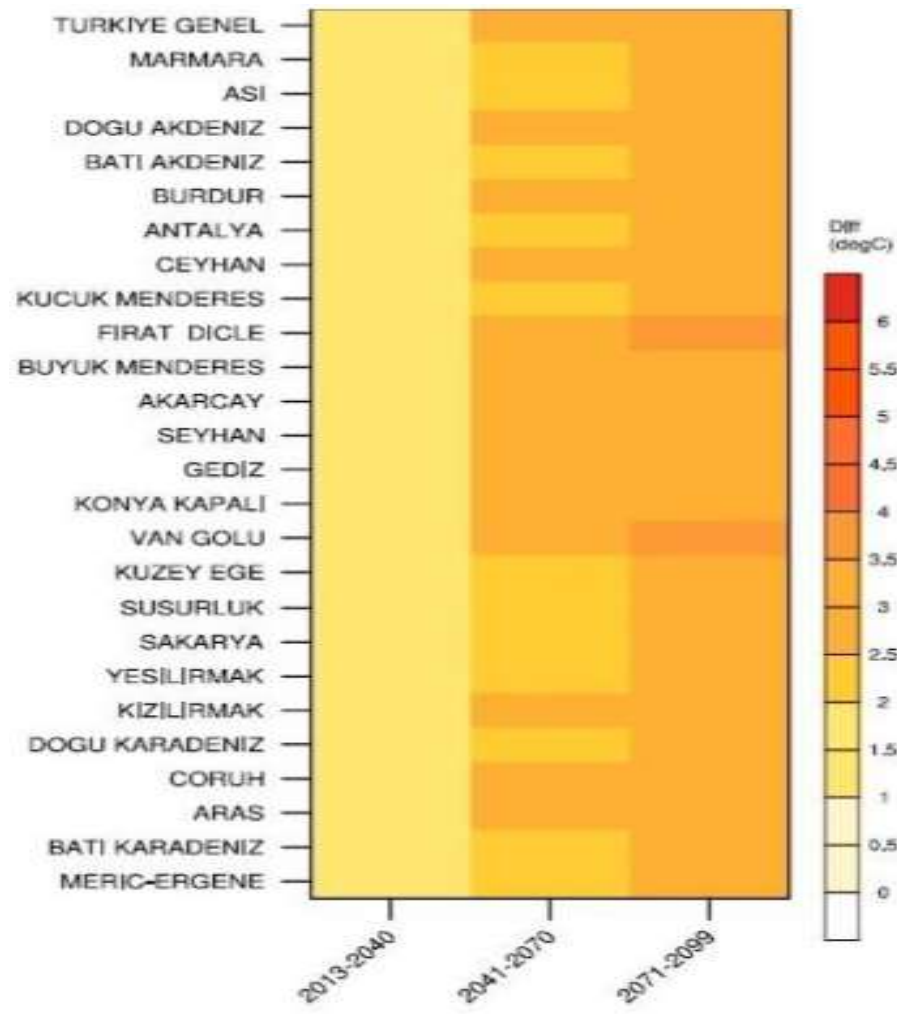

$\mathrm{Bu}$ bulgular ışığında havzada, gelecekte ortalama 3-5 ${ }^{\circ}$ C'lik sıcaklık artışları ki bu artışın sürekli olarak gerçekleşmesi beklenmektedir. Yağış̧ların ise özellikle projeksiyonun ilk döneminde (2011-2040) artma eğiliminde olmakla beraber ikinci ve üçüncü dönemde \%10-20 aralığında bir azalış göstermesi olasıdır.

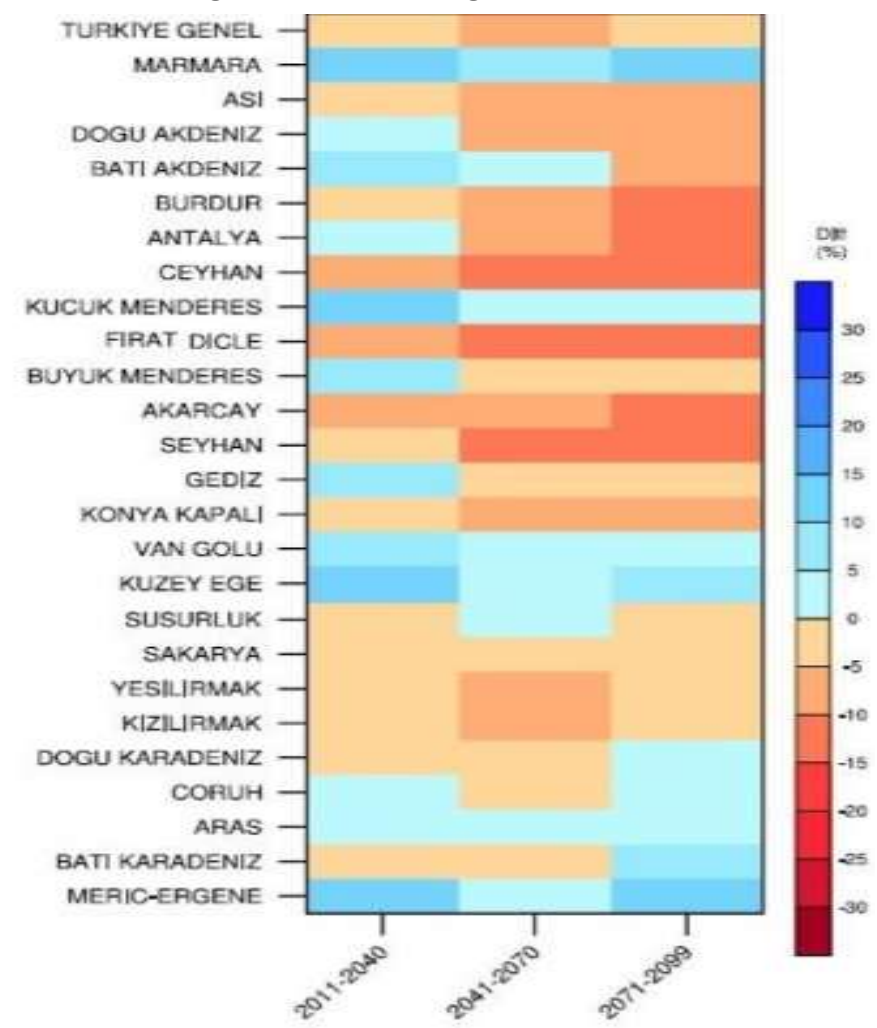

Şekil 1. RCP4.5’e göre havza sıcaklık ve yağışlarının referans yıllardan farkları (MGM 2014).
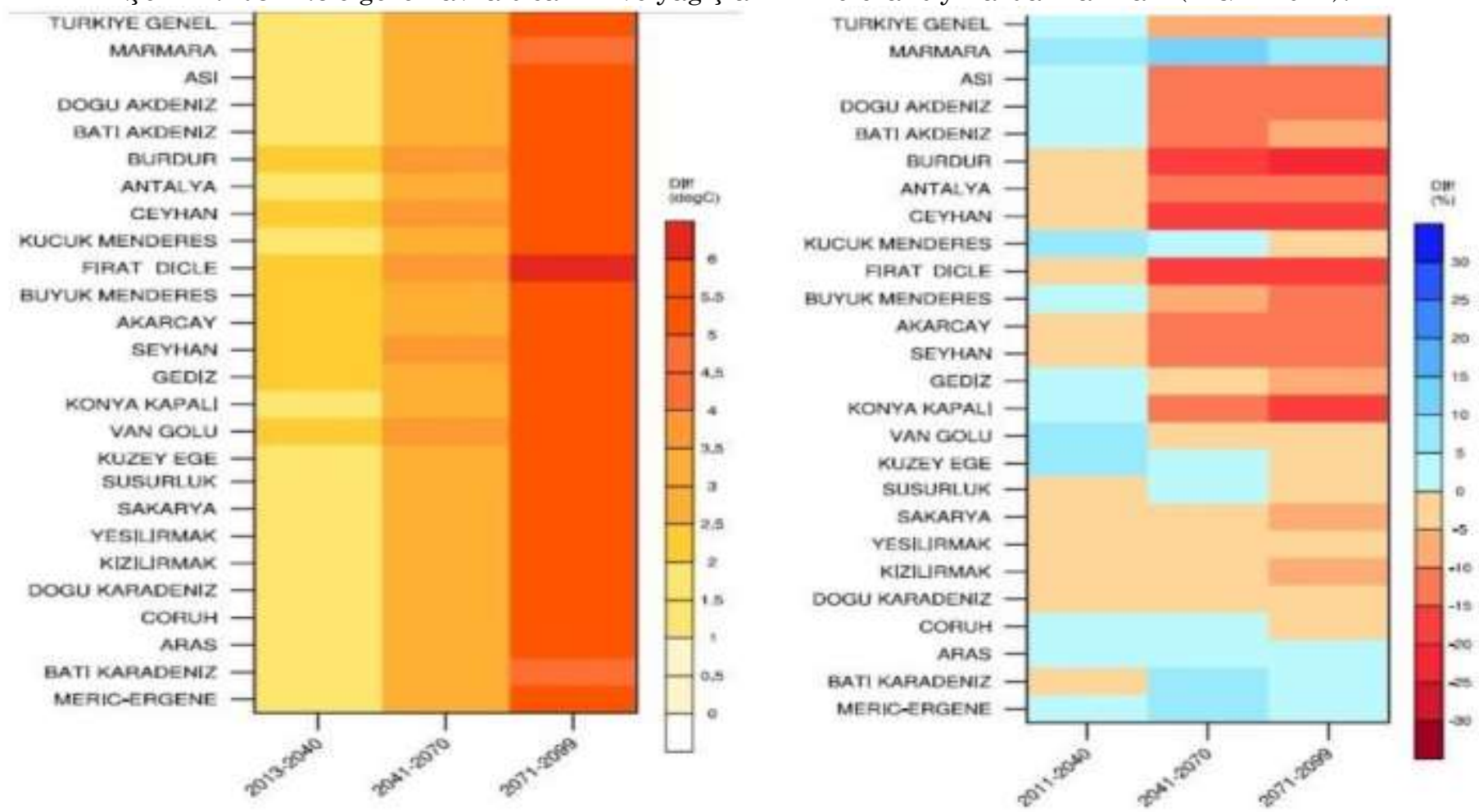

Şekil 2. RCP8.5’e göre havza sıcaklık ve yağışlarının referans yıllardan farkları (MGM, 2014). 


\section{ARAŞTIRMA BULGULARI}

\section{Üreticilerin Sosyo-Demografik Özellikleri ve Arazi- Üretim Bilgileri}

Küçük Menderes Havzasında yürütülen çalışmaya dahil olan üreticilerin yaşları 18 ila 81 arasında ve yaş ortalamaları yaklaşık 49 olarak bulunmuştur. Üreticilerin tarımsal deneyimleri 25 yıldır. Bu durum üreticilerin ömürlerinin yarısında tarım sektöründe faaliyet gösteren tecrübeli üreticiler olduklarını ortaya koymaktadır. Üreticilerin ortalama eğitim sürelerinin 6 yıl olduğu ve genel olarak 4 kişilik çekirdek ailelere sahip oldukları görülmektedir (Çizelge 1).

Çizelge 1. Üreticilerin Demografik Özellikleri

\begin{tabular}{lcccc}
\hline \multicolumn{5}{c}{ Ortalama Std. Sapma } \\
\hline Yaş (Yıl) & 48,98 & 14,036 & 18 & 81 \\
\hline $\begin{array}{l}\text { Ĕgitim süresi } \\
\text { (Yıl) }\end{array}$ & 6,42 & 2,886 & 0 & 18 \\
\hline $\begin{array}{l}\text { Ailedeki } \\
\text { birey sayısı }\end{array}$ & 3,85 & 1,676 & 1 & 10 \\
\hline $\begin{array}{l}\text { Tarımdaki } \\
\text { deneyim (Yıl) }\end{array}$ & 25,29 & 13,976 & 1 & 65 \\
\hline
\end{tabular}

Üreticilerin \%41'i hayvancılıkla uğraşmakta, \%22'si tarım dışı bir işte çalışmakta; \%40'ının ise tarım dışı bir gelir kaynağına sahip olduğu görülmektedir. Üreticilerin \%72'sinin tarımla uğraşmaktan memnun oldukları saptanmıştır. Üreticilerin aylık gelir düzeyleri incelendiğinde ağırlıklı olarak 2501-5000 TL $(\% 23,4)$ ve $2001-2500$ TL $(\% 22,2)$ gelir aralıklarında kümelendiklerini görmek mümkündür.

Üreticilerin üretim döneminde işledikleri ortalama arazi büyüklüğü 38,58 da.'dır ve bu araziler yaklaşık 4 parselden oluşmaktadırlar. Ortalama arazi büyüklüğünün \%81'ini (31,51 da) mülk arazi, \%14'ünü $(5,80 \mathrm{da})$ kira arazi ve \%1'ini $(1,45 \mathrm{da})$ ortak arazi oluşturmaktadır. Ayrıca işlenen arazi büyüklügünün $\% 52$ 'si sulanan (20,15 da), \%42'si (18,42 da) ise sulanmayan arazilerden oluşmaktadır. Çalışmaya dahil edilen üreticilerin ağırlıklı olarak yetiştirdikleri ürünler incelendiğinde; silajlık mısır, patates, süs bitkileri ve karpuz tek yıllık ürünler olarak zeytin, incir, kiraz ve ceviz ise çok ylllık ürünler olarak ortaya çıkmıştır.

\section{Üreticilerin İklim Değişikliği Farkındalıkları}

Üreticilere iklim değişikliği kavramını bilip bilmedikleri sorulmuş ve üreticilerin $\% 25$ i "biliyorum", \%51'i “kısmen bilgi sahibiyim" ve \%24'ü de "bilgim yok" olarak bu soruyu cevaplamıştır. Üreticilere iklim değişikliğinin 3 farklı tanımı yöneltilmiş ve kendilerine en doğru gelen tanımı seçmeleri istenmiştir, üreticilerin yalnızca \%27'si doğru tanımı olan "İklim değişikliği; aslında uzun yıllar içerisinde sürekli yaşanan ancak insan eli ile etkileri arttırılmış bir olaydır" tanımını tercih etmişlerdir.

Üreticilerin 2017 yılında, geçmiş 15 yıllık periyodu değerlendirmelerini ve iklimde bir değişiklik gözlemleyip gözlemlemediklerini belirtmeleri istenmiştir. Üreticilerin \%98'i iklimde bir değişiklik yaşandığını dile getirmiştir. Bu üreticilere yaşanan değişikliği ve değişikliğin boyutu sorulduğunda ise; sıcaklık $(4,53)$ ve kuraklığın $(4,63)$ çok arttığını, yağışların azalığını $(1,61)$, ekstrem olayların ve nemin ise geçtiğimiz yıllardan pek farklı olmadığını belirtmişlerdir (Çizelge 2). Ayrıca üreticiler bu iklimsel değişikliklerin yaşadıkları yörede yaklaşık 10 yıldır gözlemlendiğini belirtmişlerdir.

Çizelge 2. Üreticilere göre yaşadıkları yörede yaşanan iklimsel değişiklikler

\begin{tabular}{lcc}
\hline & Ortalama & Std. Sapma \\
\hline Kuraklık & 4,63 & 0,57 \\
Sicaklık & 4,53 & 0,66 \\
Nem & 3,24 & 0,95 \\
Sel olayları & 3,14 & 0,74 \\
Firtına olayları & 3,12 & 0,60 \\
Dolu olayları & 3,09 & 0,81 \\
Don olayları & 3,08 & 0,88 \\
Yağış & 1,61 & 0,90 \\
\hline
\end{tabular}

1. Çok Azaldı 2. Azaldı 3. Değişmedi 4. Arttı 5. Cok Arttı

Şimdilerde hissedilmekte olan iklim değişikliği etkilerinin gelecekte hangi periyotta daha da yoğun bir şekilde etkilerini hissettireceğini sorduğumuzda üreticilerin \%50'si “önümüzdeki 10 yıl içerisinde" yanıtını vermişlerdir. Bu durum üreticilerin iklim değişikliğinin yoğun etkilerini kısa zaman içerisinde göstermesini beklediğini ortaya koymaktadır (Şekil 3).

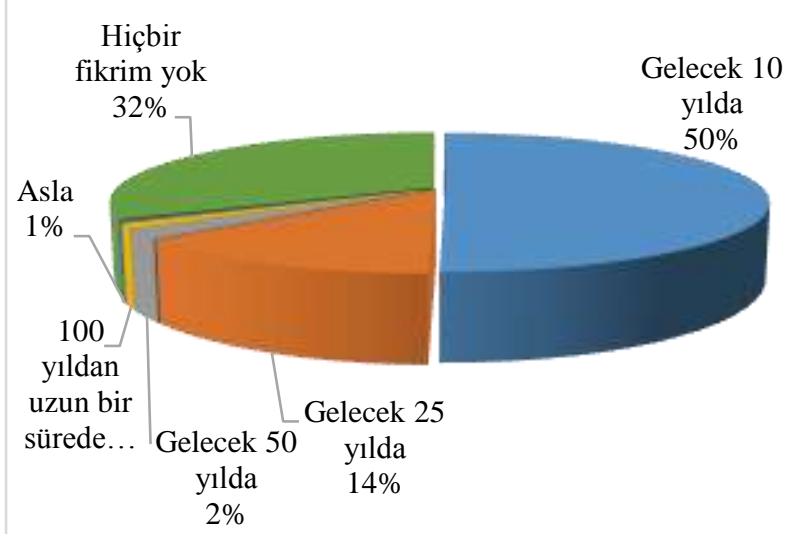

Şekil 3. Üreticilere göre iklim değişikliği etkilerinin gelecekte artı̧̧ gösterme durumu

Buradan yola çıkarak üreticilere "İklim değişikliği sizi endişelendiriyor mu?" sorusu yöneltildiğinde 4,48 ölçek ortalaması ile iklim değişikliğinin onları endişelendirdiğini beyan etmişlerdir.

Üreticiler iklim değişikliğinin nedenleri ile ilgili olarak, sırasıyla; sanayileşme $(4,39)$, ağaç kesme $(4,21)$ 
ve kentleşmenin $(4,09)$ iklim değişikliğine neden olan etmenlerin başında yer aldığını, çeltik üretimi $(2,05)$, hayvancılık faaliyeti $(1,66)$ ve et tüketiminin $(1,39)$ ise iklim değişikliğine neden olmadığını belirtmişlerdir (Çizelge 3). Bu durum üreticilerin iklim değişikliğine doğrudan neden olan etmenler konusunda bilinçli olduğu, dolaylı etmenler konusunda ise yeteri kadar bilinçli olmadığını göstermektedir.
Araştırmada üreticilerin iklim değişikliği açısından gerekli gördüğü uygulama ve politikaları kabul etme durumları incelenmiştir. Üreticiler, basınçlı sulama sistemleri için teşvik verilmesi $(4,55)$ ve iklim değişikliği ile mücadeleye yönelik yayım desteği verilmesine $(4,51)$ kesinlikle katılmakta; diğer uygulama ve politikalara ise orta düzeyde katılmaktadır (Çizelge 4).

Çizelge 3. Üreticilere göre iklim değişikliğine neden olan etmenler

\begin{tabular}{lccccccc} 
& $\mathbf{1}$ & $\mathbf{2}$ & $\mathbf{3}$ & $\mathbf{4}$ & $\mathbf{5}$ & Ortalama & Std. Sapma \\
\hline Sanayileşme & 4 & 5 & 12 & 49 & 101 & 4,39 & 0,916 \\
Ağaç kesme & 13 & 7 & 6 & 50 & 95 & 4,21 & 1,184 \\
Kentleşme & 12 & 11 & 16 & 43 & 89 & 4,09 & 1,226 \\
Kimyasal ilaç kullanımı & 16 & 8 & 12 & 63 & 72 & 3,98 & 1,236 \\
Kimyasal gübre kullanımı & 19 & 11 & 13 & 62 & 66 & 3,85 & 1,306 \\
Fosil yakıt kullanma & 26 & 15 & 26 & 48 & 56 & 3,54 & 1,415 \\
Anız yakma & 38 & 17 & 15 & 36 & 65 & 3,43 & 1,597 \\
Araç kullanma & 35 & 14 & 26 & 44 & 52 & 3,37 & 1,499 \\
Tarımsal atıklar & 38 & 17 & 25 & 50 & 41 & 3,23 & 1,483 \\
Aşırı sulama & 38 & 37 & 12 & 42 & 42 & 3,08 & 1,530 \\
Uçak yolculuğu & 50 & 14 & 58 & 29 & 20 & 2,74 & 1,353 \\
Celtik üretimi & 79 & 21 & 58 & 9 & 4 & 2,05 & 1,108 \\
Hayvancıllk faaliyeti & 107 & 33 & 18 & 8 & 5 & 1,66 & 1,036 \\
Et tüketimi & 130 & 17 & 22 & 2 & - & 1,39 & 0,754 \\
1)Kesimi
\end{tabular}

1)Kesinlikle Sebep Olmuyor 2)Sebep Olmuyor 3)Ne Sebep Oluyor Ne Sebep Olmuyor 4)Sebep Oluyor 5)Kesinlikle Sebep Oluyor

Çizelge 4. Üreticilerin olası uygulama/ politikaları kabul durumu

\begin{tabular}{lcc} 
& Ortalama & Std. Sapma \\
\hline Basınçlı sulama sistemleri için teşvik verilmeli & 4,55 & 0,855 \\
İklim değişikliği ile mücadeleye yönelik yayım desteği verilmeli & 4,51 & 0,770 \\
Düşük yakıt tüketimli tarımsal makinelerin kullanılması için teşvik verilmeli & 4,04 & 1,180 \\
Çevre dostu girdilere destek verilmeli & 3,85 & 1,376 \\
Çeşit/Ürün değişikliğine teşvik verilmeli & 3,66 & 1,381 \\
İklim değişikliği için sigorta oluşturulmalı & 3,47 & 1,516 \\
Meraların korunması ve rasyon eğitimi verilmeli & 3,12 & 1,659 \\
\hline
\end{tabular}

1.Kesinlikle katılmıyorum 2. Katılmıyorum 3.Ne Katılıyorum ne katılmıyorum 4.Katılıyorum 5.Kesinlikle Katılıyorum

\section{SONUÇ ve ÖNERILER}

Özellikle tarımın olmazsa olmazı olan suyu ana tema olarak ele alması ve bu açıdan önemi daha da fazla olan akarsu havzalarının iklim değişikliğinden nasıl ve ne şekilde etkileneceğinin ortaya konulması önemlidir. Yapılan çalışmalar ışığında Küçük Menderes Havzasında gelecekte ortalama $3-5{ }^{\circ}$ C'lik sıcaklığın artacağı, yağışların ise \%10-20 aralığında azalacağını söylemek mümkündür. $\mathrm{Bu}$ öngörümler mevcut su arzı konusunda sıkıntı yaşayan havzanın daha da sıkıntı çekeceğine dair sinyaller vermektedir. Küçük Menderes Havzasında çalışmaya dahil olan üreticilerin yaş ortalaması yaklaşık 49 olup, uzun yıllar boyunca tarımsal faaliyet içerisinde yer almış tecrübeli üreticilerdir. Havzadaki üreticilerin iklim değişikliği hakkında fikir sahibi oldukları ancak bilgi düzeyi olarak yeterli bir noktada olmadıklarını söylemek mümkündür. Bu görüşten yola çıkarak; üreticiler iklimsel değişimin ve bu duruma yol açan doğrudan etkilerin nispeten farkındadırlar ancak, dolaylı etmenler konusunda bilgi eksiklikleri bulunmaktadır. Buna rağmen, üreticiler bilgi eksikliklerinin farkında olup konu ile ilgili bilgi, bilinç ve algı düzeylerinin artması, daha bilinçli bir şeklide konuyu ele alabilmek için yayım çalışmaları yapılmasını istemekte ve beklemektedir.

Mevcut durumda tarımsal üretim için iklim değişikliğine uyum adına gerçekleştirilen uygulamalar yetersizdir ve üreticilerin bu duruma uyum sağlayabilmesi için yeterli maddi imkanları olmadığı aşikardır. Yapılan çalışmalarda oluşturulan projeksiyonların da belirttiği ve üreticinin de mevcut durumu değerlendirirken tasdik ettiği gibi havzada şu an bile kuraklık yaşanmakta ve bu kuraklığın daha da vahim durumlara neden olma ihtimali her geçen gün artmaktadır. Bu noktada havza bazlı ya da bölgesel kuraklık eylem planlarının oluşturulması ve devam eden planların da tamamlanması elzemdir. Bunun 
yanında, iklim değişikliği için yutak alanlar olarak önemli bir konumda olan tarım, orman ve çayır-mera arazileri korunmalı ve etkinlikleri arttırılmalıdır.

Havzada önümüzdeki yıllarda gerçekleşmesi beklenen sıcaklık artışı ve yağışlardaki azalma riski mevcut su kaynaklarının etkin bir şekilde kullanılması ihtiyacını doğurmuştur. $\mathrm{Bu}$ da ancak basınçlı sulama sistemlerinin kullanımının yaygınlaştırılması ile mümkündür. Üreticiler tarafından bakıldığında da, basınçlı sulama sistemleri kullanılarak sulama yönteminde değişikliğe gidilmesi mevcut sorunların çözümü için etkili olacaktır. Yine su kaynaklarının su talebini karşılayamıyor oluşu ve bu durumun gelecekte daha da artacak olması havza için üretim deseninde önlemler alınması ihtiyacinı doğurmaktadır. $\mathrm{Bu}$ noktada kuraklığa dayanıklı çeşitlerin üretim desenine dahil edilmesine ve su talebi bol olan ürünlerden yavaş yavaş vazgeçilmesi gerekecektir.

Sadece sulama yöntemleri ve ürün deseninde yapılacak değişiklikler, iklim değişikliğinin Küçük Menderes Havzasında yaşanacak olumsuz etkilerini ancak bir noktaya kadar baskılayabilecektir. Tarımsal üretim yöntemlerinde de iyileşme olması bu sürecin doğru yönetilmesi için önem teşkil etmektedir. İyi Tarım Uygulamaları (ITU) ve organik tarım gibi sürdürülebilir tarımsal uygulamalar hem iklim değişikliği hem de çevre açısından önemli olup destek ve teşviklerle cazip hale getirilmelidir. Bu noktada ülkemizde her ne kadar doğrudan iklim değişikliğine uyum uygulamalarının yetersiz olduğunu dile getirsek de, ÇATAK ve benzeri uygulamalar iklim değişikliğine uyum açısından önemlidir. Özellikle, iklim değişikliği ile uyum ve mücadele açısından yapılması elzem olan uygulamaların birçoğunu bünyesinde barındıran ÇATAK programının, daha da genişletilmesi yararlı olacaktır.

İklim değişikliğinin etkilerini inceleyen havza bazlı çalışma sayısı yetersizdir. Yapılan sınırlı sayıdaki çalışmada ise, tarımsal üretimin en önemli paydaşı olan üreticilerin konuyu nasıl algıladıkları ve ne gibi çözüm önerileri olduğunun göz ardı edildiği dikkat çekmektedir. Tabi ki bu çalışmalar yürütülürken ve çözüm yolları oluştururken üreticileri de sürece dahil etmek hem çalışmaların kalitesini hem de uygulanabilirliğini arttıracaktır. Bu gibi çalışmaların sayı ve nitelik olarak artması gerek havza gerekse ülke tarımının sürdürülebilirliği açısından önem teşkil etmektedir.

\section{KAYNAKÇA}

Akyüz Y, Atış E 2016. Türkiye'de İklim Değişikliği Tarım Etkileşiminin İki Yönüyle İncelenmesi. Uluslararası Katılımlı 2. İklim Değişimi ve Tarım Etkileşimi Çalıştayı. 08-09 Kasım 2016, Şanlıurfa.
Cline WR 2007. Global Warming and Agriculture, Impact Estimates by Country. Center For Global Development. Peterson İnstitute For İnternational Economics. Washington, DC, July 2007.

Dellal İ, McCarl BA, Butt T 2011. The Economic Assessment of Climate Change on Turkish Agriculture, Journal of Environmental Protection and Ecology, 12(1): 376-385.

Dellal İ, Ünüvar Fİ, Polat K, Bolat M, Ünal M 2016. İklim Değişikliği Ve Kuraklığın Türkiye'de Tarımda Etkilerinin Değerlendirilmesi. TAGEM 14 ARGE 49. Ankara Üniversitesi, Mart 2016, Ankara.

Demircan M, Demir Ö, Atay H, Eskioğlu O, Yazıcı B, Gürkan H, Tuvan A, Akçakaya A 2014. Türkiye'de Yeni Senaryolara Göre İklim Değişikliği Projeksiyonları, Ankara.

IFPRI 2009. Climate Change Impact on Agriculture and Costs of Adaptation. Updated October 2009.

MGM 2014. İklim Projeksiyonlarına Göre Akarsu Havzalarında Sıcaklık ve Yağış Değerlendirmesi, Araştırma Dairesi Başkanlığı Klimatoloji Şube Müdürlüğü. Şubat 2014.

MGM 2016. Türkiye ve Çevresi İçin İklim Projeksiyonları Projesi, Ön sonuçları.

Muluk ÇB, Kurt B, Turak A, Türker A, Çalışkan MA, Balkız Ö, Gümrükçü S, Sarıgül G, Zeydanlı U 2013. Türkiye'de Suyun Durumu ve Su Yönetiminde Yeni Yaklaşımlar: Çevresel Perspektif. İş Dünyası ve Sürdürülebilir Kalkınma Derneği - Doğa Koruma Merkezi.

Newbold P 1995. Statistics for Business and Economics. Prentice-Hall International. New Jersey.

Schreiner C, Henriksen, EK, Hansen PJK 2005. Climate education: Empowering today's youth to meet tomorrow's challenges. Studies In Science Education, 41: 3-50.

T.C. Çevre ve Orman Bakanlığı 2010. Havza Koruma Eylem Planları - Küçük Menderes Havzası. TÜBİTAK, MAM Cevre Enstitüsü.

T.C. Çevre ve Şehircilik Bakanlığ 1 2013. Türkiye İklim Değişikliği 5. Bildirimi. Mayıs 2013, Ankara.

T.C. Çevre ve Şehircilik Bakanlığı 2016. Türkiye İklim Değişikliği 6. Ulusal Bildirimi.

T.C. Orman ve Su İşleri Bakanlığı 2016. Su Yönetimi Genel Müdürlüğü. İklim Değişikliğinin $\mathrm{Su}$ Kaynaklarına Etkisi Projesi. Proje Nihai Raporu, Ek 8 - Küçük Menderes Havzası.

Türkeş M 1997. Hava Ve İklim Kavramları Üzerine. TÜBİTAK Bilim ve Teknik Dergisi. 355:36-37, Ankara.

UNFCCC 1992. United Nations Framework Convention on Climate Change. FCCC/INFORMAL/84, GE.05-62220 (E) 200705. United Nations 